\title{
Article
}

\section{The Role of Nitrogen Dioxide in the Production of Sulfate during Chinese Haze-Aerosol Episodes}

\author{
Lijie Li, Michael R Hoffmann, and Agustin J. Colussi \\ Environ. Sci. Technol., Just Accepted Manuscript • DOI: 10.1021/acs.est.7b05222 • Publication Date (Web): 29 Jan 2018
}

Downloaded from http://pubs.acs.org on January 30, 2018

\section{Just Accepted}

"Just Accepted" manuscripts have been peer-reviewed and accepted for publication. They are posted online prior to technical editing, formatting for publication and author proofing. The American Chemical Society provides "Just Accepted" as a free service to the research community to expedite the dissemination of scientific material as soon as possible after acceptance. "Just Accepted" manuscripts appear in full in PDF format accompanied by an HTML abstract. "Just Accepted" manuscripts have been fully peer reviewed, but should not be considered the official version of record. They are accessible to all readers and citable by the Digital Object Identifier (DOI®). "Just Accepted" is an optional service offered to authors. Therefore, the "Just Accepted" Web site may not include all articles that will be published in the journal. After a manuscript is technically edited and formatted, it will be removed from the "Just Accepted" Web site and published as an ASAP article. Note that technical editing may introduce minor changes to the manuscript text and/or graphics which could affect content, and all legal disclaimers and ethical guidelines that apply to the journal pertain. ACS cannot be held responsible for errors or consequences arising from the use of information contained in these "Just Accepted" manuscripts. 


\title{
The Role of Nitrogen Dioxide in the Production of Sulfate during Chinese Haze-Aerosol Episodes
}

\author{
Lijie Li, Michael R. Hoffmann and Agustín J. Colussi* \\ Department of Environmental Science \& Engineering, California Institute of Technology, \\ Pasadena, CA 91125, United States
}

Haze events in China megacities involve the rapid oxidation of $\mathrm{SO}_{2}$ to sulfate aerosol. Given the

weak photochemistry taking place in these optically thick hazes, it has been hypothesized that

$11 \mathrm{SO}_{2}$ is mostly oxidized by $\mathrm{NO}_{2}$ emissions in the bulk of $\mathrm{pH}>5.5$ aerosols. Since $\mathrm{NO}_{2}(\mathrm{~g})$

12 dissolution in water is very slow and aerosols are more acidic, we decided to test such

13 hypothesis. Herein, we report that $>95 \% \mathrm{NO}_{2}(\mathrm{~g})$ disproportionates: $2 \mathrm{NO}_{2}(\mathrm{~g})+\mathrm{H}_{2} \mathrm{O}(\mathrm{l})=\mathrm{H}^{+}+$

$14 \mathrm{NO}_{3}{ }^{-}(\mathrm{aq})+\mathrm{HONO}(\mathrm{R} 1)$, upon hitting the surface of $\mathrm{NaHSO}_{3}$ aqueous microjets exposed to

$15 \mathrm{NO}_{2}(\mathrm{~g})$ for $<50 \mu \mathrm{s}$, thereby giving rise to strong $\mathrm{NO}_{3}{ }^{-}(\mathrm{m} / \mathrm{z}=62)$ signals detected by online

16 electrospray mass spectrometry, rather than oxidizing $\mathrm{HSO}_{3}{ }^{-}(\mathrm{m} / \mathrm{z}=81)$ to $\mathrm{HSO}_{4}{ }^{-}(\mathrm{m} / \mathrm{z}=97)$ in

17 the relevant $\mathrm{pH}$ 3-6 range. Since $\mathrm{NO}_{2}(\mathrm{~g})$ will be consumed via $\mathrm{R} 1$ on the surface of typical

18 aerosols, the oxidation of $\mathrm{S}(\mathrm{IV})$ may in fact be driven by the $\mathrm{HONO} / \mathrm{NO}_{2}^{-}$generated therein.

$19 \mathrm{~S}(\mathrm{IV})$ heterogeneous oxidation rates are expected to primarily depend on the surface density and

20 liquid water content of the aerosol, which are enhanced by fine aerosol and high humidity.

21 Whether aerosol acidity affects the oxidation of $\mathrm{S}(\mathrm{IV})$ by $\mathrm{HONO} / \mathrm{NO}_{2}{ }^{-}$remains to be elucidated. 


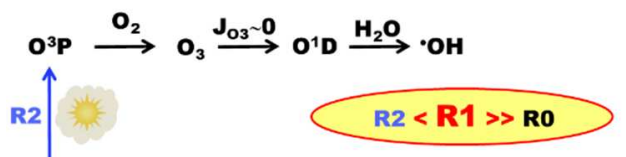




\section{Introduction}

Chinese megacities often experience haze events $(\mathrm{HE})^{1-7}$ that severely impair visibility and

32 induce acute health effects. ${ }^{5-6,8-11}$ Hazes mainly consist of sulfate aerosols produced in the

33 atmospheric processing of $\mathrm{SO}_{2}$ and $\mathrm{NO}_{2}$ emissions under particularly adverse meteorological

34 conditions. ${ }^{12-14}$ Current models of chemistry in HE significantly underestimate sulfate formation

35 revealing that the mechanism of $\mathrm{SO}_{2}$ oxidation is not well understood. ${ }^{15-17}$ The drastic

36 attenuation of actinic radiation in hazes, ${ }^{18-21}$ suggests that $\mathrm{SO}_{2}$ is oxidized by $\mathrm{NO}_{2}(\mathrm{~g})$ in

37 heterogeneous processes on the aerosol itself, rather than in the gas-phase by photogenerated

38 oxidants. The details of such process are uncertain.

39 Known $\mathrm{SO}_{2}$ atmospheric oxidation pathways include gas-phase reactions with OH-radicals

40 and stabilized Criegee intermediates, and aqueous phase reactions with $\mathrm{O}_{3},{ }^{22} \mathrm{H}_{2} \mathrm{O}_{2}$, organic

41 peroxides, $\mathrm{NO}_{\mathrm{x}}$, as well as autoxidation catalyzed by transition metal ions. The low

42 concentrations of photogenerated oxidants ${ }^{18,23-30}$ implies that the chemistries of $\mathrm{SO}_{2}$ and $\mathrm{NO}_{2}$ in

$43 \mathrm{HE}$ are intertwined. These observations have led to hypothesizing that $\mathrm{HSO}_{3}{ }^{-}(\mathrm{aq})$ is rapidly

44 oxidized by the $\mathrm{NO}_{2}(\mathrm{~g})$ dissolved in aqueous aerosol phases assumed to be at $\mathrm{pH}>5.5$, reaction

45 R0:

$$
2 \mathrm{NO}_{2}(\mathrm{aq})+\mathrm{HSO}_{3}^{-}(\mathrm{aq})+\mathrm{H}_{2} \mathrm{O}(\mathrm{l})=2 \mathrm{H}^{+}(\mathrm{aq})+\mathrm{HSO}_{4}^{-}(\mathrm{aq})+2 \mathrm{NO}_{2}^{-}(\mathrm{aq})
$$

47 on the basis of R0 rates measured in bulk water. ${ }^{31,32,33}$ Good agreement between field 48 observations and model results on sulfate aerosol formation in $\mathrm{HE}$ could be obtained by 49 assuming that $\mathrm{R} 0$ proceeds on the surface $\mathrm{pH}>5.5$ aqueous aerosols at the rates previously 50 reported at $\mathrm{pH} \sim 6$ in bulk water. ${ }^{31-34}$ However, the assumptions that aerosols are at $\mathrm{pH}>5.5$, and

$51 \mathrm{NO}_{2}(\mathrm{~g})$ dissolves in large surface-to-volume aerosol droplets as $\mathrm{NO}_{2}(\mathrm{aq})$ as it does in bulk water

52 may not apply. ${ }^{35-45}$ Most recent studies suggest that HE aerosols are in fact in the $\mathrm{pH}$ 3-5 
53 range. ${ }^{46-52}$ Previous laboratory experiments have shown that collisions of ppm $\mathrm{NO}_{2}(\mathrm{~g})$ (i.e., in the

54 absence of $\mathrm{N}_{2} \mathrm{O}_{4}$ ) with the surface of aqueous electrolyte solutions (but not on the surface of pure

55 water) yield $\mathrm{NO}_{3}^{-}(\mathrm{aq})$ via a first-order in $\left[\mathrm{NO}_{2}\right]$ hydrolytic disproportionation catalyzed by

56 anions, reaction $\mathrm{R} 1 .^{42,45}$

$$
2 \mathrm{NO}_{2}(\mathrm{~g})+\mathrm{H}_{2} \mathrm{O}(\mathrm{l})=\mathrm{H}^{+}+\mathrm{NO}_{3}{ }^{-}(\mathrm{aq})+\mathrm{HONO}
$$

58 The facts that $\mathrm{NO}_{2}(\mathrm{~g})$ is weakly soluble in pure water (Henry's law constant $\mathrm{H} \sim 0.01 \mathrm{M} \mathrm{atm}^{-1}$ )

59 and its uptake coefficient on pure water very small: $\gamma \sim 1 \times 10^{-7},{ }^{53}$ its dissolution) in water is

60 unfavorable both by kinetic and thermodynamic reasons. The aqueous phase of most

61 atmospheric aerosols, however, is not pure water. In 2009, we found that anions greatly enhance

$62 \mathrm{NO}_{2}(\mathrm{~g})$ uptake on water. The rate determining step involves the capture of $\mathrm{NO}_{2}(\mathrm{~g})$ by anions $\mathrm{X}^{-}$

63 as $\mathrm{X}-\mathrm{NO}_{2}^{-}$at air-aqueous interfaces, ${ }^{42,}{ }^{45}$ followed by the reaction of $\mathrm{X}-\mathrm{NO}_{2}^{-}$with a second

$64 \mathrm{NO}_{2}(\mathrm{~g})$. This phenomenon accounts for the outstanding discrepancy (by a $\sim 10^{3-4}$ factor) between

65 the $\mathrm{NO}_{2}(\mathrm{~g})$ uptake coefficients measured in neat water ${ }^{41,53}$ vs those determined on NaCl-seeded

66 droplets in a cloud chamber. ${ }^{35,39,54}$ Since HE aerosols naturally contain organic and inorganic

67 anions, the expectation was that the fate of $\mathrm{NO}_{2}(\mathrm{~g})$ would be determined by $\mathrm{R} 1$ at the relevant

68 aerosol air-aqueous interfaces.

69 Given the societal and economic impact of HE, we deemed important to elucidate the actual

70 role of $\mathrm{NO}_{2}(\mathrm{~g})$ in the production of sulfate aerosol under relevant conditions. Herein we report

71 experiments in which aqueous $1 \mathrm{mM} \mathrm{NaHSO}_{3}$ microjets (containing $3 \mathrm{mM}$ of added EDTA to

72 inhibit the potential autoxidation of $\mathrm{HSO}_{3}{ }^{-}$catalyzed by pervasive transition metal ions) ejected

73 from a stainless steel syringe are exposed to $5 \mathrm{ppm} \mathrm{NO}_{2}(\mathrm{~g})$ for $\leq 50 \mu$ s in 1 atm of $\mathrm{N}_{2}(\mathrm{~g})$ at 298

74 K. Reactant and product ions formed on the outermost water layers of the liquid microjets are

75 detected within $1 \mathrm{~ms}$ by online electrospray ionization mass spectrometry (o-ESI-MS). This 
76 technique has been used in our laboratory to investigate a suite of gas-liquid reactions at the air-

77 water interface. ${ }^{55-61}$ The analysis of our experimental results focuses on the fate of $\mathrm{NO}_{2}(\mathrm{~g})$, and

78 the competition between $\mathrm{R} 0$ vs $\mathrm{R} 1$ during $\mathrm{NO}_{2}(\mathrm{~g})$ collisions with the surface of aqueous $\mathrm{HSO}_{3}{ }^{-}$

79 solutions under conditions relevant to HE. To our knowledge, this is the first study to provide

80 direct experimental evidence on the extent of $\mathrm{S}(\mathrm{IV})$ oxidation by $\mathrm{NO}_{2}(\mathrm{~g})$ on the surface of

81 aqueous electrolyte solutions over a wide $\mathrm{pH}$ range.

82

94 liquid microjets issuing (at $11 \mathrm{~cm} \mathrm{~s}^{-1}$ ) from the tip of the syringe are pneumatically stripped and

95 nebulized into charged microdroplets by $\mathrm{N}_{2}(\mathrm{~g})$ flowing at $>250 \mathrm{~m} \mathrm{~s}^{-1}$ through a coaxial sheath.

96 Anions contained in the charged microdroplets are detected by online ESI mass spectrometry in

97 the $\mathrm{m} / \mathrm{z}$ 50-100 range. Anion detection was optimized by setting the drying gas temperature at

$98325^{\circ} \mathrm{C}$, and the capillary voltage at $3250 \mathrm{~V}$. Fresh solutions were prepared with Milli-Q water 
$99\left(18.2 \mathrm{M} \Omega \cdot \mathrm{cm}\right.$ at $\left.25{ }^{\circ} \mathrm{C}\right)$ that had been sparged with $\mathrm{N}_{2}(\mathrm{~g})$ for $8 \mathrm{~h}$ to remove dissolved $\mathrm{O}_{2}$ (except 100 as indicated) within 5 minutes prior to injection, in a glove box at $<1 \mathrm{ppm} \mathrm{O}_{2}(\mathrm{~g})$. The $\mathrm{pH}$ of 101 solutions was adjusted by adding $\mathrm{NaOH}(\mathrm{aq})$ or $\mathrm{HCl}(\mathrm{aq})$ and measured with a calibrated $\mathrm{pH}$ 102 meter. Throughout, reported $\mathrm{pH}$ values correspond to those measured in the bulk of solutions. 103 Sodium bisulfite solution (40\% w/w, Sigma-Aldrich), hydrochloric acid ( $>30 \% \mathrm{w} / \mathrm{w}$, Sigma104 Aldrich), sodium hydroxide ( $\geq 99.0 \%$, Sigma-Aldrich), and ethylenediaminetetraacetic acid 105 (EDTA, $>99.0 \%$, Sigma-Aldrich), and $48.75 \pm 2 \% \mathrm{ppm} \mathrm{NO}_{2}(\mathrm{~g})$ in $\mathrm{N}_{2}(\mathrm{~g}$ ) (Airgas), were used as 106 received. The actual $\mathrm{NO}_{2}(\mathrm{~g})$ concentration at the surface of the aqueous microjets is 10 times 107 smaller (5 ppm) due to dilution by the nebulizer gas.

\section{3. Results}

\section{3. $1 \mathrm{HSO}_{3}{ }^{-}$mass spectral intensities on aqueous surfaces}

$114 \mathrm{HSO}_{3}{ }^{-} \mathrm{m} / \mathrm{z}=81$ mass spectral signal intensities $\left(\mathrm{I}_{81}\right.$, normalized to their maximum value,

$\left.115 \mathrm{I}_{81, \max }\right)$ measured by o-ESI-MS at the gas-aqueous interface of $1 \mathrm{mM} \mathrm{NaHSO}_{3}$ aqueous microjets 116 as functions of bulk $\mathrm{pH}$ are shown as blue datapoints in Figure 2. The red trace corresponds to $117\left[\mathrm{HSO}_{3}^{-}\right] /\left[\mathrm{HSO}_{3}{ }^{-}\right]_{\max }$ values calculated from reported acidity constants in bulk water: $\mathrm{pK}_{\mathrm{a} 1}$ $118\left(\mathrm{H}_{2} \mathrm{O} \cdot \mathrm{SO}_{2} \rightleftharpoons \mathrm{HSO}_{3}{ }^{-}+\mathrm{H}^{+}\right)=1.8, \mathrm{pKa}_{2}\left(\mathrm{HSO}_{3}{ }^{-} \rightleftharpoons \mathrm{SO}_{3}{ }^{-}+\mathrm{H}^{+}\right)=7.2$. Experimental mass spectral 119 data clearly display $\mathrm{HSO}_{3}{ }^{-}$deficits at $\mathrm{pH}<5$ relative to calculated values, which are due to $\mathrm{SO}_{2}$

120 losses to the gas-phase. This is considered a feature particular to the $\mathrm{HSO}_{3}{ }^{-} / \mathrm{SO}_{2}$ system because 121 the titration curves of less volatile acids and bases determined in this setup were in accordance 
122 with bulk $\mathrm{pK}_{\mathrm{a}}$ values ${ }^{58,65}$ The experimental $\mathrm{HSO}_{3}{ }^{-}$signal intensities vs $\mathrm{pH}$ data of Fig. 2 provide 123 the reference for analyzing the extent of S(IV) oxidation in the following sections.

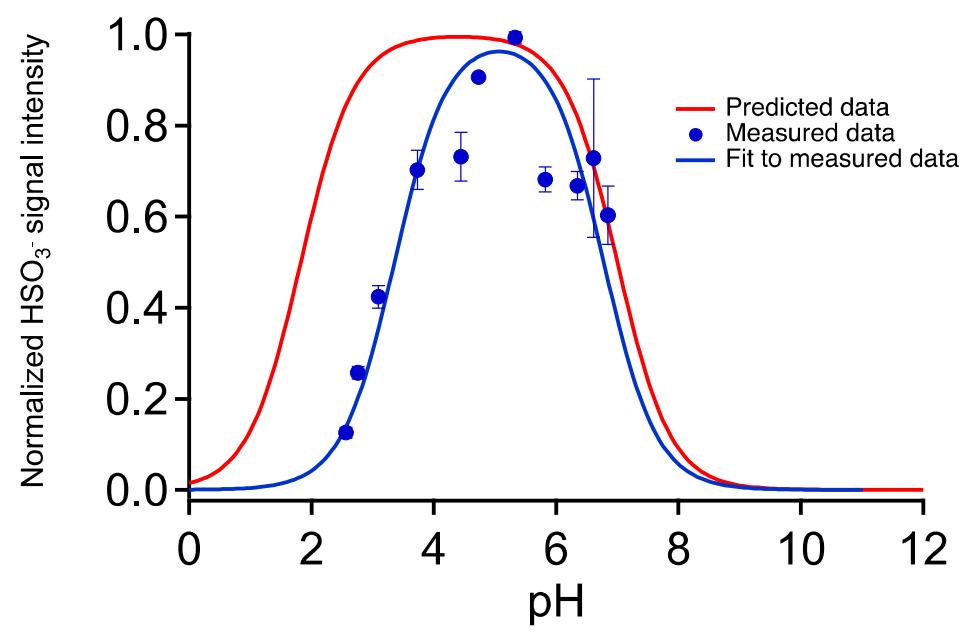

125 Figure 2. Normalized $\mathrm{m} / \mathrm{z}=81\left(\mathrm{HSO}_{3}{ }^{-}\right)$signals measured by o-ESI-MS on the surface of 126 aqueous $1 \mathrm{mM} \mathrm{NaHSO}$ (aq) microjets as a function of bulk pH (blue symbols and line). $\mathrm{HSO}_{3}{ }^{-}$ 127 mole fractions calculated from $\mathrm{pK}_{\mathrm{a} 1}\left(\mathrm{H}_{2} \mathrm{O} \cdot \mathrm{SO}_{2} \rightleftharpoons \mathrm{HSO}_{3}{ }^{-}+\mathrm{H}^{+}\right)=1.8, \mathrm{pK}_{\mathrm{a} 2}\left(\mathrm{HSO}_{3}{ }^{-} \rightleftharpoons \mathrm{SO}_{3}{ }^{-}+\mathrm{H}^{+}\right)$ $128=7.2$ in bulk water (red line).

\section{3. $2 \mathrm{NO}_{2}(\mathrm{~g})$ reactions on aqueous electrolyte surfaces}

Mass spectra acquired before and during exposure of $\mathrm{pH} \sim 5\left(1 \mathrm{mM} \mathrm{HSO}_{3}^{-}+3 \mathrm{mM}\right.$ EDTA $)$

131 aqueous microjets to $5 \mathrm{ppm} \mathrm{NO}_{2}(\mathrm{~g})$ for $\leq 50 \mu$ s are shown in Figure 3. The main feature is the

132 appearance of a strong $\mathrm{NO}_{3}{ }^{-} \mathrm{m} / \mathrm{z}=62$ signal, in contrast with the minimal variations displayed

133 by both $\mathrm{HSO}_{3}{ }^{-} \mathrm{m} / \mathrm{z}=81$ and $\mathrm{HSO}_{4}{ }^{-} \mathrm{m} / \mathrm{z}=97$ signals upon $\mathrm{NO}_{2}(\mathrm{~g})$ exposure. This outcome

134 means that $\mathrm{NO}_{2}(\mathrm{~g})$ molecules hitting the surface of $\mathrm{pH} \sim 5 \mathrm{HSO}_{3}{ }^{-}$microjets mainly undergo fast

135 (within $50 \mu \mathrm{s}$ ) disproportionation, leaving barely any $\mathrm{NO}_{2}$ for diffusing into the bulk liquid and, 136 supposedly, participate in R0. The following section explores the effect of $\mathrm{pH}$ on the competition 137 between R0 and R1. 
139

140

141

142

143

144

145

146

147

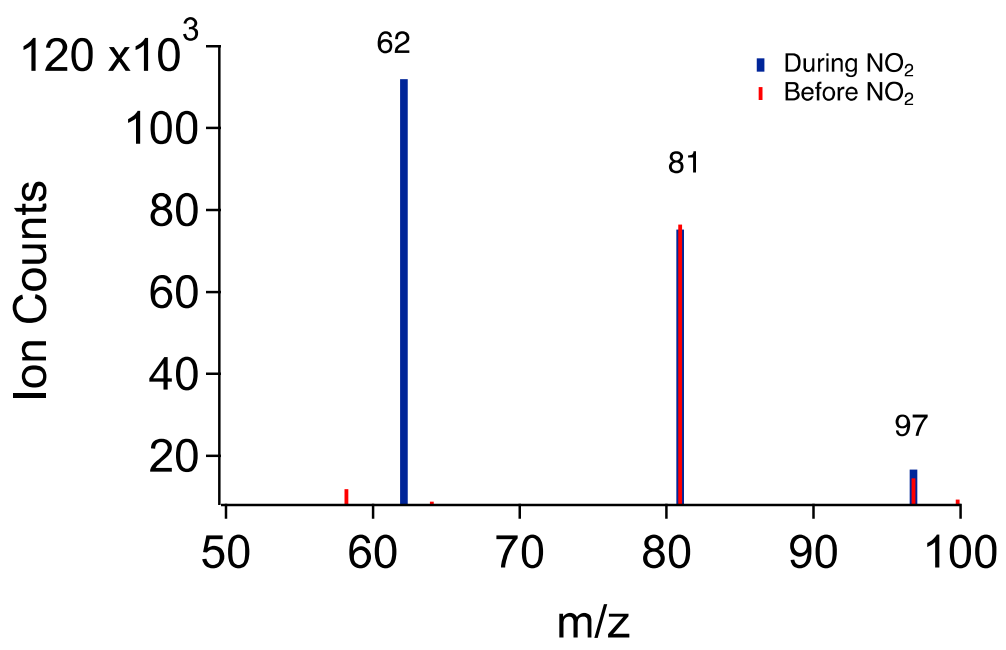

Figure 3. ESI mass spectra of the surface of aqueous $1 \mathrm{mM} \mathrm{NaHSO}_{3}+3 \mathrm{mM}$ EDTA, $\mathrm{pH} \sim 5$ microjets before and after exposure to $5 \mathrm{ppm} \mathrm{NO}_{2}(\mathrm{~g})$. Note the presence of minor $\mathrm{HSO}_{4}{ }^{-}(\mathrm{m} / \mathrm{z}=$ 97) impurities in the initial solutions.

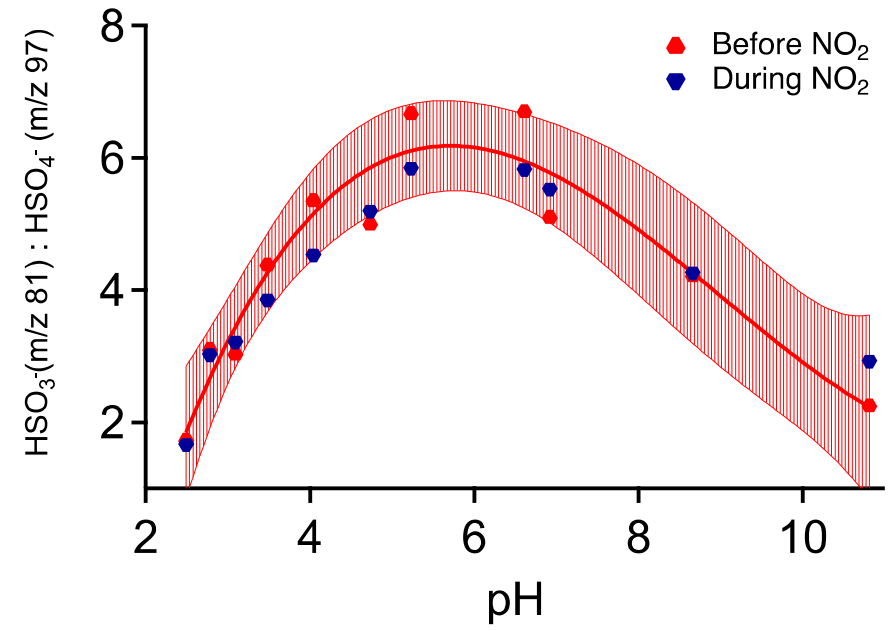

Figure 4. Red symbols, line and $95 \%$ confidence band correspond to the ratio of $\mathrm{HSO}_{3}{ }^{-} / \mathrm{HSO}_{4}{ }^{-}=$ $\mathrm{I}_{81} / \mathrm{I}_{97}$ signal intensities on the surface of $\left(1 \mathrm{mM} \mathrm{NaHSO}_{3}+3 \mathrm{mM}\right.$ EDTA in $\mathrm{N}_{2}(\mathrm{~g})$-sparged MQ water) microjets as a function of bulk $\mathrm{pH}$. Blue symbols: after exposure to $5 \mathrm{ppm} \mathrm{NO}_{2}(\mathrm{~g})$ for $<$ $50 \mu \mathrm{s}$. 


\section{3 The oxidation of S(IV) on aqueous surfaces}

The extent of $\mathrm{HSO}_{3}^{-}(\mathrm{aq})$ oxidation by $\mathrm{NO}_{2}(\mathrm{~g})$, expressed as the ratio of $\left[\mathrm{HSO}_{3}^{-}\right] /\left[\mathrm{HSO}_{4}{ }^{-}\right] \propto$

$158 \mathrm{I}_{81} / \mathrm{I}_{97}$ signal intensities, as a function of $\mathrm{pH}$ is shown in Figure $4 . \mathrm{I}_{81}$ values correspond to 159 measured $\mathrm{I}_{81}$ signals corrected for the depressing effect of the $\mathrm{NO}_{3}{ }^{-}$simultaneously produced via

$160 \mathrm{R} 1$ at the air-aqueous interface (see below). ${ }^{63,66}$ Figure 4 clearly shows that the extent of $\mathrm{HSO}_{3}{ }^{-}$

161 (aq) oxidation via R0 is minimal throughout, barely exceeding experimental error in the $\mathrm{pH}$ 3-6 162 range relevant to HE.

163 We quantified the fraction of $\mathrm{NO}_{2}(\mathrm{~g})$ that oxidizes $\mathrm{HSO}_{3}{ }^{-}(\mathrm{aq})$ at the air-aqueous interface as $164 f_{\mathrm{R} 0}$, defined by equation E1. In E1, $\Delta_{81}$ is calculated from the decrease of measured $\mathrm{I}_{81}$ signals, $165 \Delta_{81}$, corrected for the $\mathrm{NO}_{3}{ }^{-}$depressing effect mentioned above, which is multiplied by the ratio: $\beta$ $166=\mathrm{I}_{62} / \mathrm{I}_{82}$, of the o-ESI mass spectral measured in $\left(1 \mathrm{mM} \mathrm{HSO}_{3}{ }^{-}+1 \mathrm{mM} \mathrm{NO}_{3}{ }^{-}\right)$equimolar 167 solutions at each $\mathrm{pH}$ to convert $\mathrm{I}_{81}$ decrements into equivalent $\Delta_{62} \mathrm{NO}_{3}{ }^{-}$changes.

$$
f_{R 0}=\frac{\Delta_{81^{\prime}}}{\Delta_{81^{\prime}+\Delta_{62}}}
$$

We found that $f_{\mathrm{R} 0}$ increases from $<6 \%$ within $\mathrm{pH} 3.0$ and 6.0 up to $42 \%$ at $\mathrm{pH} 10.8$. It also 170 increases with acidity up to $16 \%$ at $\mathrm{pH} 2.5$ (Figure 5). This finding means that the anion171 catalyzed hydrolytic disproportionation of $\mathrm{NO}_{2}(\mathrm{~g})$ on aquated aerosol surfaces, reaction $\mathrm{R} 1$, will 172 outcompete R0 throughout, particularly under atmospherically relevant acidic conditions. ${ }^{35,39,41 \text {, }}$

$17343,45,57$ We have shown that most electrolytes increase the uptake coefficient of $\mathrm{NO}_{2}(\mathrm{~g})$ from $\gamma<$ $1741.0 \times 10^{-7}$ in pure water, ${ }^{37}$ up to $\gamma=1 \times 10^{-3}-1 \times 10^{-4}$ at air-aqueous electrolyte interfaces. ${ }^{35,39,41 \text {, }}$ $175{ }^{45,57}$ The mechanism of enhancement involves trapping $\mathrm{NO}_{2}(\mathrm{~g})$ by $\mathrm{X}^{-}$as $\mathrm{X}_{-} \mathrm{NO}_{2}{ }^{-}$at the air-water 176 interface, which can react further with $\mathrm{NO}_{2}(\mathrm{~g}) .{ }^{45}$ This interfacial process is expected to dominate 177 the fate of $\mathrm{NO}_{2}(\mathrm{~g})$ during $\mathrm{HE}$ due to the large surface-to-volume ratio of aerosol microdroplets. 178 We have previously shown that the decay of $\mathrm{NO}_{2}(\mathrm{~g})$ on aqueous aerosols via reaction $\mathrm{R} 1$ 
179 accounts for the similar $\sim 4 \mathrm{~h} \mathrm{NO}_{2}(\mathrm{~g})$ decay half-lives measured by satellite sightings of urban

180 plumes over world megacities ranging from Singapore to Moscow latitudes. ${ }^{42}$ We pointed out

181 that if, as generally assumed, $\mathrm{NO}_{2}(\mathrm{~g})$ were removed by gas-phase $\mathrm{OH}$-radicals via: $\mathrm{NO}_{2}(\mathrm{~g})+$

$182 \cdot \mathrm{OH}(\mathrm{g})=\mathrm{HNO}_{3}(\mathrm{~g})$, much longer decay half-lives should have been observed in winter and at

183 high latitudes, given that "OH-radicals follow the sun". 67

184 Next, we performed experiments in which we analyzed, within 5 min via o-ESI-MS, freshly 185 prepared $\mathrm{HSO}_{3}{ }^{-}$solutions in air-saturated water without added EDTA.We detected $\mathrm{SO}_{3}{ }^{-} \mathrm{m} / \mathrm{z}=$ 18680 signals that increase linearly with $\mathrm{pH}$ (Figure S3). The formation of $\mathrm{SO}_{3}{ }^{-}$is ascribed to the 187 autoxidation of $\mathrm{HSO}_{3}^{-}$catalyzed by the omnipresent traces of transition metal ions in our 188 solutions. ${ }^{68}$ Whether this process makes a significant contribution to the oxidation of S(IV) under 189 HE conditions is the subject of further studies. ${ }^{69-70}$ Additonal experiments carried out by 190 exposing such $\mathrm{HSO}_{3}{ }^{-}$solutions (in air-saturated deionized water without added EDTA) to $\mathrm{NO}_{2}(\mathrm{~g})$, 191 Figure $\mathrm{S} 4$, led to $\mathrm{I}_{81} / \mathrm{I}_{97}$ ratios similar to those of Figure 4 results $\mathrm{NO}_{2}(\mathrm{~g})$, meaning that $\mathrm{NO}_{2}$ 192 makes negligible contributions to S(IV) autoxidation in our $50 \mu$ s timeframes.

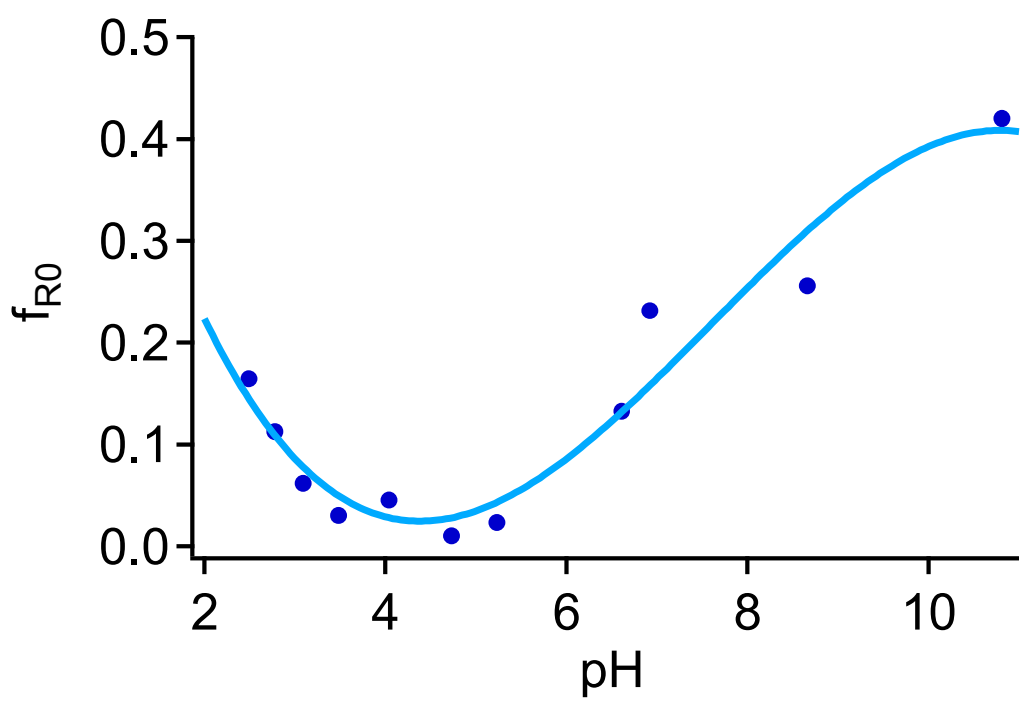

193

194

195

196
Figure 5. The fraction of $\mathrm{NO}_{2}(\mathrm{~g})$ that contributes to $\mathrm{S}(\mathrm{IV})$ oxidation, $f_{R 0}$ (equation E1) as a function of $\mathrm{pH}$. 


\section{Discussion}

\section{1 Indirect role of $\mathrm{NO}_{2}(\mathrm{~g})$ in the oxidation of $\mathrm{S}(\mathrm{IV})$}

Our findings open up new perspectives on the mechanism of $\mathrm{S}(\mathrm{IV})$ oxidation by $\mathrm{NO}_{2}(\mathrm{~g})$

200 during HE. They underscore the fact that the stoichiometry of R0 could not account for the

201 formation of $\mathrm{NO}_{3}{ }^{-}$in $\mathrm{HE}{ }^{32-33}$ This is so because if $\mathrm{NO}_{2}(\mathrm{~g})$ were the only available oxidant and,

202 moreover, it were consumed in $\mathrm{R} 0, \mathrm{~N}(\mathrm{IV}) \mathrm{O}_{2}$ could not be oxidized to $\mathrm{N}(\mathrm{V}) \mathrm{O}_{3}{ }^{-}$. Any valid 203 mechanism should explain: (1) how are both $\mathrm{S}(\mathrm{IV}) \mathrm{O}_{2}$ and $\mathrm{N}(\mathrm{IV}) \mathrm{O}_{2}$ oxidized to $\mathrm{HS}(\mathrm{VI}) \mathrm{O}_{4}{ }^{-}$and $204 \mathrm{~N}\left(\mathrm{~V} \mathrm{O}_{3}{ }^{-}\right.$, and (2) how is HONO produced.

205 We analyzed the fate of $\mathrm{NO}_{2}(\mathrm{~g})$ by considering its reactive uptake on the aerosol via $\mathrm{R} 1$ and 206 its photolysis by scattered solar radiation via R2 under representative HE conditions.

$$
\mathrm{NO}_{2}(\mathrm{~g})+\mathrm{h} v(\lambda \leq 420 \mathrm{~nm})=\mathrm{O}\left({ }^{3} \mathrm{P}\right)+\mathrm{NO}
$$

208 Rate constants for the reactive uptake of $\mathrm{NO}_{2}(\mathrm{~g}), \mathrm{k}_{\mathrm{R} 1}$, were estimated with equation E2 from the 209 kinetic theory of gases.

$$
\mathrm{k}_{\mathrm{R} 1}=1 / 4 \gamma \mathrm{v}_{\mathrm{NO} 2}(\mathrm{~S} / \mathrm{V})
$$

211 where $\mathrm{v}_{\mathrm{NO} 2}=3.7 \times 10^{2} \mathrm{~m} \mathrm{~s}^{-1}$ is the mean thermal speed of $\mathrm{NO}_{2}(\mathrm{~g})$ at $298 \mathrm{~K}, \gamma=10^{-3}-10^{-4}$ is the 212 estimated range of the reactive uptake coefficient of $\mathrm{NO}_{2}(\mathrm{~g})$ on the surface of aqueous electrolyte 213 solutions, ${ }^{45}$ and $\mathrm{S} / \mathrm{V}$ (in $\mu \mathrm{m}^{2} \mathrm{~m}^{-3}$ ) is the surface density of aerosols. Aerosols consist of 214 submicron particles with $\mathrm{S} / \mathrm{V}$ values up to $\sim 2 \times 10^{-3} \mathrm{~m}^{-1}$ during hazy days, and values $\sim 5$ times 215 smaller in clear days. ${ }^{33}$ By assuming that $\gamma=10^{-3}, \mathrm{~S} / \mathrm{V}=2 \times 10^{-3} \mathrm{~m}^{-1}$ and $4 \times 10^{-4} \mathrm{~m}^{-1}$, we 216 estimate: $\mathrm{k}_{\mathrm{R} 1} \sim 2 \times 10^{-4} \mathrm{~s}^{-1}$ and $\mathrm{k}_{\mathrm{R} 1} \sim 4 \times 10^{-5} \mathrm{~s}^{-1}$ on hazy and clear days, respectively.

217 The low $\mathrm{O}_{3}(\mathrm{~g})$ concentrations measured during $\mathrm{HE}$ indicate that the photolysis of $\mathrm{NO}_{2}(\mathrm{~g})$, 218 which generates the $\mathrm{O}\left({ }^{3} \mathrm{P}\right)$ atoms involved in $\mathrm{O}_{3}(\mathrm{~g})$ formation: $\mathrm{O}_{2}+\mathrm{O}\left({ }^{3} \mathrm{P}\right)+\mathrm{M}=\mathrm{O}_{3}+\mathrm{M}$, is 219 much reduced due to the severe attenuation of actinic sunlight during HE. We estimated time- 
220 and space-averaged photolysis rate constants, $\mathrm{k}_{\mathrm{R} 2}$, by using the National Center for Atmospheric

221 Research Tropospheric Ultraviolet Visible (TUV) Radiation Model with environmental

222 parameters within the ranges reported for aerosol optical properties and aerosol radiative forcing

223 parameters (see S.3). ${ }^{24-25}$ Our estimates: $\left(\mathrm{k}_{\mathrm{R} 1}\right)_{\mathrm{h}} /\left(\mathrm{k}_{\mathrm{R} 2}\right)_{\mathrm{h}} \sim 0.5-1.2,\left(\mathrm{k}_{\mathrm{R} 1}\right)_{\mathrm{c}} /\left(\mathrm{k}_{\mathrm{R} 2}\right)_{\mathrm{c}} \sim 0.01-0.1(\mathrm{~h}=\mathrm{hazy}$

$224 \mathrm{c}=$ clear), are semi-quantitatively consistent with the above premise, and illustrate how the

225 competition between R1 and R2 shifts from hazy to clear days. (See S.3). However, we consider

226 that TUV calculations on the competition between R1 and R2 only provide a lower bound to

$227\left(\mathrm{k}_{\mathrm{R} 1}\right)_{\mathrm{h}} /\left(\mathrm{k}_{\mathrm{R} 2}\right)_{\mathrm{h}}$, because $\mathrm{NO}_{2}(\mathrm{~g})$ is not expected to be uniformly distributed but accumulate in the

228 lower layers of dense hazes, where there is minimal actinic radiation and photochemical activity.

229 Together, our estimates and experimental results support the view that the leading pathway

230 for $\mathrm{NO}_{2}(\mathrm{~g})$ during $\mathrm{HE}$ is its heterogeneous disproportionation into $\left(\mathrm{NO}_{3}{ }^{-}+\mathrm{HONO} / \mathrm{NO}_{2}^{-}+\mathrm{H}^{+}\right)$

231 via $\mathrm{R} 1$. Note that $\mathrm{R} 1$ is autocatalytic because it ultimately contributes to increase the mass and

$232 \mathrm{~S} / \mathrm{V}$ of the aerosols on which it takes place. The rapid development of HE is in fact consistent

233 with such an autocatalytic process. The fact that relative humidity increments are tracked by

234 increased particle number concentrations and surface area density $\mathrm{S} / \mathrm{V}\left(\mu \mathrm{m}^{2} \mathrm{~m}^{-3}\right)$ of $\mathrm{PM}_{2.5}$,

235 particularly in the accumulation mode, also support the notion that the liquid particles present

236 under such conditions grow from autocatalytic heterogeneous processes. ${ }^{71}$

$237 \mathrm{R} 1$ accounts for the direct formation of $\mathrm{NO}_{3}{ }^{-}$and $\mathrm{HONO}$, and would also account for the

238 formation of $\mathrm{HSO}_{4}{ }^{-}$if the $\mathrm{HONO} / \mathrm{NO}_{2}{ }^{-}$produced in $\mathrm{R} 1$ could ultimately oxidize $\mathrm{S}(\mathrm{IV}$ ) (see

239 Figure 6). ${ }^{72-78}$ As a result, since $f_{\mathrm{R} 0} \leq 0.1$ in the realistic $\mathrm{pH} 3-6$ range, i.e., nearly independent

240 of $\mathrm{pH}$ (Figure 5), the acidity/basicity of $\mathrm{HE}$ aerosols could be a relevant parameter to S(IV)

241 oxidation rates if subsequent processes were to depend on aerosol $p H .{ }^{79-80}$ Therefore, our

242 conclusion that the main pathway for $\mathrm{NO}_{2}(\mathrm{~g})$ in $\mathrm{HE}$ is $\mathrm{R} 1$ will stand regardless of future 
243 assessments of aerosol $\mathrm{pH}$. The parameters that may affect a heterogeneous process such as R1

244 could be a combination of aerosol S/V and aerosol liquid water content, both of which depend on

245 relative humidity. ${ }^{79-80}$ We suggest that the apparent dependence of sulfate formation rates on

246 ammonia neutralization of aerosol particles may be the result of cross-correlations between

247 aerosol acidity and the actual causal parameters. In this connection, we wish to point out that the

248 enhancing "ammonium" effect on the oxidation rates of $\mathrm{SO}_{2}(\mathrm{~g})$ by $\mathrm{NO}_{2}(\mathrm{~g})$ on aqueous solutions

249 might be due to the presence of $\mathrm{HSO}_{4}{ }^{-}$anions that capture $\mathrm{NO}_{2}(\mathrm{~g})$ at the aerial interface, as

250 explained above. ${ }^{33}$ It is also important to realize that Clifton et al., results on the homogeneous

251 reaction rates of $\mathrm{HSO}_{3}{ }^{-}(\mathrm{aq})$ with the $\mathrm{NO}_{2}(\mathrm{aq})$ produced in situ within bulk solution via $\mathrm{NO}_{2}{ }^{-}(\mathrm{aq})$

252 radiolysis, ${ }^{54}$ are not applicable to the heterogeneous processes being considered here, which

253 involve $\mathrm{NO}_{2}(\mathrm{~g})$ as reactant.

\section{4. 2 HONO/ $\mathrm{NO}_{2}^{-}$as $\mathrm{S}(\mathrm{IV})$ oxidizers}

255 Aqueous $\mathrm{HONO}$ and $\mathrm{NO}_{2}{ }^{-}$can oxidize $\mathrm{HSO}_{3}{ }^{-}$to $\mathrm{HSO}_{4}{ }^{-}$in the $\mathrm{pH} \mathrm{3-5}$ range of $\mathrm{HE}$ aerosols.

$256 \mathrm{HONO}$ and $\mathrm{NO}_{2}^{-}$reductions to $\mathrm{NO}: \mathrm{E}^{\circ}\left(\mathrm{HONO}+\mathrm{H}^{+}+\mathrm{e}=\mathrm{NO}+\mathrm{H}_{2} \mathrm{O}\right)=0.75 \mathrm{~V}^{\circ} \mathrm{E}^{\circ}\left(\mathrm{NO}_{2}^{-}+2 \mathrm{H}^{+}\right.$

$\left.257+\mathrm{e}=\mathrm{NO}+\mathrm{H}_{2} \mathrm{O}\right)=1.08 \mathrm{~V}$ or to $\mathrm{N}_{2} \mathrm{O}: \mathrm{E}^{\circ}\left(2 \mathrm{HONO}+4 \mathrm{H}^{+}+4 \mathrm{e}=\mathrm{N}_{2} \mathrm{O}+3 \mathrm{H}_{2} \mathrm{O}\right)=1.06 \mathrm{~V}^{\circ} \mathrm{E}^{\circ}(2$

$\left.258 \mathrm{NO}_{2}^{-}+6 \mathrm{H}^{+}+4 \mathrm{e}=\mathrm{N}_{2} \mathrm{O}+3 \mathrm{H}_{2} \mathrm{O}\right)=1.04 \mathrm{~V}$, could also drive the thermal (dark) oxidation of

$259 \mathrm{HSO}_{3}^{-}$to $\mathrm{HSO}_{4}^{-}: \mathrm{E}^{\circ}\left(\mathrm{HSO}_{3}{ }^{-}+\mathrm{H}_{2} \mathrm{O}=\mathrm{HSO}_{4}{ }^{-}+2 \mathrm{H}^{+}+2 \mathrm{e}\right)=0.15 \mathrm{~V}$ at $\mathrm{pH} 4$, depending on

260 concentrations of reactants and products. The oxidation of $\mathrm{HSO}_{3}{ }^{-}$by $\mathrm{HONO} / \mathrm{NO}_{2}{ }^{-}$however, is

261 complex and proceeds slowly via a free radical mechanism through S- and N-containing

262 intermediates. ${ }^{81-83}$ In the presence of air, $\mathrm{O}_{2}$ could participate in this process (see below). ${ }^{84}$

$263 \mathrm{HONO}$ and $\mathrm{NO}_{2}^{-}$, however, could also produce $\mathrm{OH}$ radicals at significant rates via

264 photolysis, even in optically thick hazes. Estimates made by using the TUV Radiation Model

265 show that the photolysis of HONO (from R1), reaction R3, 


$$
\mathrm{HONO}+\mathrm{h} v(\lambda \leq 390 \mathrm{~nm})=\mathrm{NO}+\cdot \mathrm{OH}
$$

267 is a stronger source of $\mathrm{OH}$-radicals than the photolysis of $\mathrm{O}_{3}(\mathrm{~g})$ even at the $[\mathrm{HONO}]=0.01\left[\mathrm{O}_{3}\right]$

268 relative abundances measured during $\mathrm{HE}^{28}$ This is due to the much larger solar irradiance in the $269 \lambda \leq 390 \mathrm{~nm}$ actinic range compared with that in the $\lambda \leq 310 \mathrm{~nm}$ range where $\mathrm{O}_{3}(\mathrm{~g})$ dissociates 270 into $\mathrm{O}\left({ }^{1} \mathrm{D}\right): \mathrm{O}_{3}+\mathrm{hv}=\mathrm{O}_{2}+\mathrm{O}\left({ }^{1} \mathrm{D}\right)$. Our estimates furthermore suggest that OH-radical 271 production rates from HONO during hazy and clear days could comparable, because faster 272 production and slower HONO photolysis under haze conditions are compensated by slower 273 production and faster HONO photolysis in clear days. (Table. S1, S.3). We therefore suggest that $274 \cdot \mathrm{OH}$ production from HONO photolysis during HE could play a significant role in sulfate 275 formation. $^{85}$

276 However, since $\mathrm{pK}_{\mathrm{a}}(\mathrm{HONO}) \sim 3,{ }^{86}$ some $\mathrm{N}(\mathrm{III})$ will be also present as $\mathrm{NO}_{2}{ }^{-}(\mathrm{aq})$ in the $\mathrm{pH}=$ 277 3-5 range. The photolysis of $\mathrm{NO}_{2}{ }^{-}(\mathrm{aq})$ also produces $\cdot \mathrm{OH}$, but at much lower rates that $\mathrm{HONO}(\mathrm{g})$, 278 both because of the integrated molar absorptivity of $\mathrm{NO}_{2}^{-} \sim 15$ times smaller than that of $\mathrm{HONO}$, 279 and the quantum yield of $\cdot \mathrm{OH}$ production: $\phi\left(\mathrm{NO}_{2}{ }^{-}(\mathrm{aq}) \rightarrow \cdot \mathrm{OH}\right) \sim 0.04$ is 25 times smaller than $280 \phi(\mathrm{HONO}(\mathrm{g}) \rightarrow \cdot \mathrm{OH})=1.0,{ }^{87}$ due to solvent cage effects. Since the reaction of $\mathrm{HSO}_{3}{ }^{-}$with $\cdot \mathrm{OH}$ 281 from the photolysis of $\mathrm{HONO} / \mathrm{NO}_{2}{ }^{-}$, and presumably as well as the thermal (dark) reaction 282 between $\mathrm{NO}_{2}{ }^{-}+\mathrm{HSO}_{3}{ }^{-}$, both proceed via free radicals, $\mathrm{O}_{2}$ is expected to participate in these 283 processes and lead to chain oxidation mechanisms.

284 The preceding considerations leads us to suggest that $\mathrm{NO}_{2}(\mathrm{~g})$ oxidizes $\mathrm{S}(\mathrm{IV})$ indirectly via 285 the free radical mechanism shown below, rather than directly via R0.

$$
2 \mathrm{NO}_{2}+\mathrm{H}_{2} \mathrm{O}=\mathrm{H}^{+}+\mathrm{NO}_{3}^{-}+\mathrm{HONO}
$$

$$
\begin{aligned}
& \mathrm{HONO}+\mathrm{hv}=\mathrm{NO}+\cdot \mathrm{OH} \\
& \cdot \mathrm{OH}+\mathrm{HSO}_{3}^{-}+\mathrm{O}_{2}=\mathrm{HSO}_{4}{ }^{-}+\mathrm{HOO} \cdot
\end{aligned}
$$




$$
\cdot \mathrm{OH}+\mathrm{RH}+\mathrm{O}_{2}=\mathrm{RO}_{\mathrm{x}}+\mathrm{HOO}
$$

$$
\mathrm{HOO} \cdot+\mathrm{NO}=\mathrm{NO}_{2}+\cdot \mathrm{OH}
$$

$$
\mathrm{NO}_{2}+\mathrm{HSO}_{3}^{-}+\mathrm{O}_{2}+\mathrm{H}_{2} \mathrm{O}=\mathrm{NO}_{3}^{-}+\mathrm{HSO}_{4}^{-}+\mathrm{H}^{+}+\cdot \mathrm{OH}
$$

292 Steps (iii) and (iv) as written are not elementary reactions but may proceed via R-OO. and H293 OO intermediates. The overall stoichiometry of $\mathrm{R} 4$ indicates that $\mathrm{NO}_{2}$ and $\mathrm{HSO}_{3}{ }^{-}$produce 294 equimolecular amounts of $\mathrm{NO}_{3}{ }^{-}$and $\mathrm{HSO}_{4}{ }^{-}$, plus an $\cdot \mathrm{OH}$ radical that can oxidize $\mathrm{HSO}_{3}{ }^{-}$as well as 295 other species, $\mathrm{RH}$. If $\cdot \mathrm{OH}$ reacts with organics $\mathrm{RH}$ instead of $\mathrm{HSO}_{3}{ }^{-}$, the $\mathrm{HOO} \cdot$ produced in (iv) 296 will regenerate $\cdot \mathrm{OH}$ react via (v) as long as there is sufficient NO remaining. Therefore, although $297 \mathrm{NO}_{2}$ may not be the direct oxidizer of $\mathrm{SO}_{2}$ during $\mathrm{HE}$, the oxidative capacity of the atmosphere 298 will still be determined by initial $\mathrm{NO}_{2}$ concentrations. As noted above, a related thermal chain 299 oxidation mechanism may be initiated by $\left(\mathrm{NO}_{2}^{-}+\mathrm{HSO}_{3}^{-}\right)$.

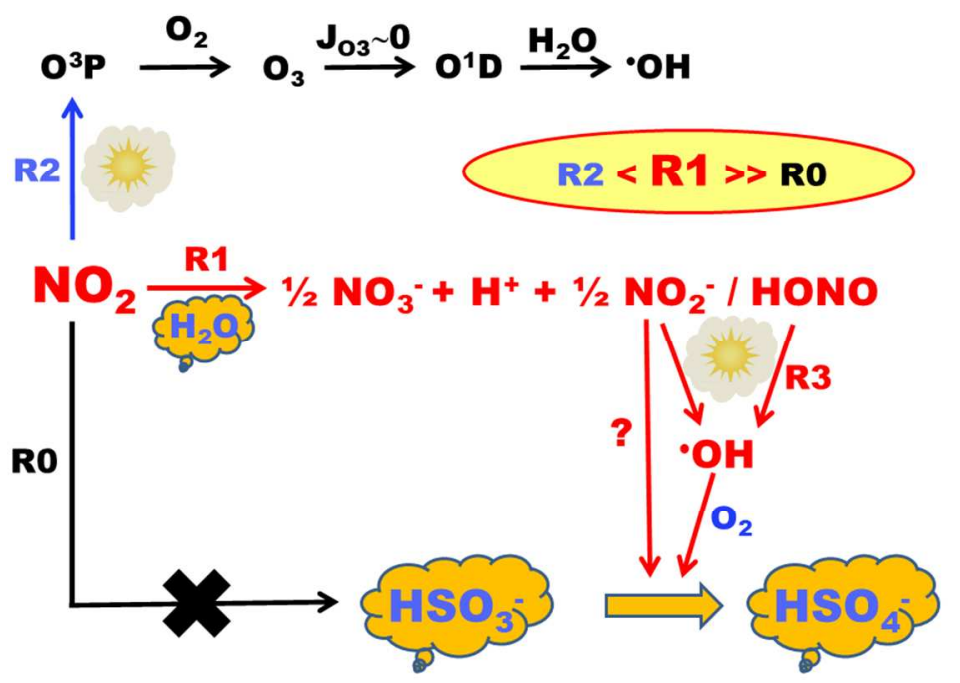

Figure 6. $\mathrm{NO}_{2}$ reactions and their impact on $\mathrm{S}(\mathrm{IV})$ oxidation during haze aerosol events.

\section{3 Atmospheric Implications}

This work focused on the particular heterogeneous chemistry that takes place during the severe wintertime haze events (HE) observed in major Chinese cities. We show that the rapid 
308 formation of sulfate aerosol during $\mathrm{HE}$ cannot be due to the direct reaction of $\mathrm{HSO}_{3}{ }^{-}$with $\mathrm{NO}_{2}$.

309 Instead, $\mathrm{S}(\mathrm{IV})$ could be oxidized indirectly by $\mathrm{NO}_{2}$ via the $\mathrm{HONO} / \mathrm{NO}_{2}^{-}$produced in its fast

310 hydrolytic disproportionation: $2 \mathrm{NO}_{2}(\mathrm{~g})+\mathrm{H}_{2} \mathrm{O}(\mathrm{l})=\mathrm{H}^{+}+\mathrm{NO}_{3}{ }^{-}(\mathrm{aq})+\mathrm{HONO}(\mathrm{R} 1)$, a process that

311 is catalyzed by anions at air-aqueous aerosol interfaces. The proposed mechanism naturally

312 accounts for the formation of $\mathrm{NO}_{3}{ }^{-}$in the aerosol phase, and the significant concentrations of

313 HONO in the gas-phase reported by all field studies. It is expected to be favored at the high

314 relative humidity and high $\mathrm{S} / \mathrm{V}$ aerosol densities prevalent in HE. We show that the photolysis of

$315 \mathrm{HONO}$ and $\mathrm{NO}_{2}^{-}$can be a significant source of $\mathrm{OH}-$ radicals even under hazy conditions, and

316 point out that the thermal reaction between $\mathrm{NO}_{2}^{-}$and $\mathrm{HSO}_{3}^{-}$also proceeds via free radicals, ${ }^{82}$

317 both of which can initiate oxidative chains in the presence of $\mathrm{O}_{2}$. Present findings suggest that

318 future field campaigns should focus on $\mathrm{OH}$-radical measurements during winter $\mathrm{HE}$, an issue that

319 has not been properly addressed in the literature. The main insight is that the relevant parameters

320 for a heterogeneous process such as R1 are the surface density S/V of aerosol hazes, which is

321 related to particle size distributions and the fluidity of the interfacial layers, rather than the

322 acidity of aerosol particles. The apparent dependence of sulfate formation rates on ammonia

323 neutralization of aerosol particles may be the result of cross-correlations between aerosol acidity

324 and the actual causal parameters. Whereas it remains true that the oxidation of $\mathrm{SO}_{2}$ during $\mathrm{HE}$ is

325 driven by primary $\mathrm{NO}_{2}$ emissions, our work, by clarifying the actual mechanism by which this

326 process is initiated, could guide future research efforts and help optimize future air pollution

327 control strategies.

328 Summing up: the direct reaction of $\mathrm{NO}_{2}(\mathrm{~g})$ with $\mathrm{HSO}_{3}{ }^{-}$on the surface of aqueous aerosols is 329 insignificant in the $\mathrm{pH} 3$ to 6 range. On the surface of aqueous electrolyte solutions, such as 330 those of $\mathrm{HE}$ aerosols, $\mathrm{NO}_{2}(\mathrm{~g})$ is mainly converted to $\mathrm{NO}_{3}{ }^{-}$plus $\mathrm{HONO} / \mathrm{NO}_{2}{ }^{-}$via hydrolytic 
331 disproportionation. The implication is that the oxidation of $\mathrm{HSO}_{3}{ }^{-}$during $\mathrm{HE}$ coul be mostly due 332 to thermal (dark) and/or photochemical reactions initiated by $\mathrm{HONO} / \mathrm{NO}_{2}$. The acidity/basicity 333 of HE aerosols could be a relevant parameter to S(IV) oxidation rates only if such processes were 334 to depend on aerosol $\mathrm{pH}$.

335 Supporting Information: Additional Figures S1 to S4. Explanatory note S0. TUV calculations 336 S1. Estimated rates of $\mathrm{HONO}$ and $\mathrm{OH}$ production: S2 and Table S1.

337 Acknowledgments: We acknowledge funding support from National Science Foundation 338 (Grants AC-1238977 \& AGS-1744353).

$339 *$ Corresponding author: ajcoluss@caltech.edu 


\section{References}

342 1. Ma, J.; Chen, Y.; Wang, W.; Yan, P.; Liu, H.; Yang, S.; Hu, Z.; Lelieveld, J., Strong Air Pollution 343 Causes Widespread Haze $\square$ Clouds over China. J. Geophys. Res. Atmospheres 2010, 115, 344 10.1029/2009JD013065.

345 2. Zheng, G.; Duan, F.; Su, H.; Ma, Y.; Cheng, Y.; Zheng, B.; Zhang, Q.; Huang, T.; Kimoto, T.; 346 Chang, D., Exploring the Severe Winter Haze in Beijing: The Impact of Synoptic Weather, Regional Transport and Heterogeneous Reactions. Atmos. Chem. Phys. 2015, 15, 2969-2983.

3. Zheng, B.; Zhang, Q.; Zhang, Y.; He, K.; Wang, K.; Zheng, G.; Duan, F.; Ma, Y.; Kimoto, T., Heterogeneous Chemistry: A Mechanism Missing in Current Models to Explain Secondary Inorganic Aerosol Formation During the January 2013 Haze Episode in North China. Atmos. Chem. Phys. 2015, 15, 2031.

4. Kulmala, M., China's Choking Cocktail. Nature 2015, 526, 497.

5. Fu, H.; Chen, J., Formation, Features and Controlling Strategies of Severe Haze-Fog Pollutions in China. Sci. Total Environ. 2017, 578, 121-138.

6. Lin, M.; Tao, J.; Chan, C.-Y.; Cao, J.-J.; Zhang, Z.-S.; Zhu, L.-H.; Zhang, R.-J., Regression Analyses between Recent Air Quality and Visibility Changes in Megacities at Four Haze Regions in China. Aerosol Air Qual. Res. 2012, 12, 1049-1061.

7. Bouarar, I.; Xuemei, W.; Brasseur, G. P., Air Pollution in Eastern Asia: An Integrated Perspective. Springer: Cham, Switzerland, 2017.

8. Xu, P.; Chen, Y.; Ye, X., Haze, Air Pollution, and Health in China. Lancet 2013, 382, 2067.

9. Huang, R.-J.; Zhang, Y.; Bozzetti, C.; Ho, K.-F.; Cao, J.-J.; Han, Y.; Daellenbach, K. R.; Slowik, J. G.; Platt, S. M.; Canonaco, F., High Secondary Aerosol Contribution to Particulate Pollution During Haze Events in China. Nature 2014, 514, 218-222.

10. Gao, J.; Woodward, A.; Vardoulakis, S.; Kovats, S.; Wilkinson, P.; Li, L.; Xu, L.; Li, J.; Yang, J.; Cao, L., Haze, Public Health and Mitigation Measures in China: A Review of the Current Evidence for Further Policy Response. Sci. Total Environ. 2017, 578, 148-157.

11. Gao, M.; Guttikunda, S. K.; Carmichael, G. R.; Wang, Y.; Liu, Z.; Stanier, C. O.; Saide, P. E.; Yu, M., Health Impacts and Economic Losses Assessment of the 2013 Severe Haze Event in Beijing Area. Sci. Total Environ. 2015, 511, 553-561.

12. Liu, Z.; Xie, Y.; Hu, B.; Wen, T.; Xin, J.; Li, X.; Wang, Y., Size-Resolved Aerosol Water-Soluble Ions During the Summer and Winter Seasons in Beijing: Formation Mechanisms of Secondary Inorganic Aerosols. Chemosphere 2017, 183, 119-131.

13. Guo, S.; Hu, M.; Zamora, M. L.; Peng, J.; Shang, D.; Zheng, J.; Du, Z.; Wu, Z.; Shao, M.; Zeng, L., Elucidating Severe Urban Haze Formation in China. Proc. Natl. Acad. Sci. U. S. A. 2014, 111, 1737317378.

14. Quan, J.; Tie, X.; Zhang, Q.; Liu, Q.; Li, X.; Gao, Y.; Zhao, D., Characteristics of Heavy Aerosol Pollution During the 2012-2013 Winter in Beijing, China. Atmos. Environ. 2014, 88, 83-89.

15. Wang, Y.; Zhang, Q.; Jiang, J.; Zhou, W.; Wang, B.; He, K.; Duan, F.; Zhang, Q.; Philip, S.; Xie, Y., Enhanced Sulfate Formation During China's Severe Winter Haze Episode in January 2013 Missing from Current Models. J. Geophys. Res. Atmospheres 2014, 119, 10,425-10,440.

381 16. Li, G.; Cao, J.; Huang, R., A Possible Pathway for Rapid Growth of Sulfate During Haze Days in 382 China. Atmos. Chem. Phys 2017, 17, 3301-3316.

383 17. Yu, H.; Ren, L.; Kanawade, V. P., New Particle Formation and Growth Mechanisms in Highly 384 Polluted Environments. Curr. Pollut. Rep. 2017, 1-9.

385 18. Hu, B.; Zhao, X.; Liu, H.; Liu, Z.; Song, T.; Wang, Y.; Tang, L.; Xia, X.; Tang, G.; Ji, D., 386 Quantification of the Impact of Aerosol on Broadband Solar Radiation in North China. Sci. Rep. 2017, 7, 38744851.

388 19. Deng, X.; Zhou, X.; Tie, X.; Wu, D.; Li, F.; Tan, H.; Deng, T., Attenuation of Ultraviolet Radiation 389 Reaching the Surface Due to Atmospheric Aerosols in Guangzhou. Chinese Science Bulletin 2012, 57, $390 \quad 2759-2766$. 
391

392

393

394

395

396

397

398

399

400

401

402

403

404

405

406

407

408

409

410

411

412

413

414

415

416

417

418

20. Xia, D.; Chen, L.; Chen, H.; Luo, X.; Deng, T., Influence of Atmospheric Relative Humidity on Ultraviolet Flux and Aerosol Direct Radiative Forcing: Observation and Simulation. Asia-Pacific J. Atmos. Sci. 2016, 52, 341-352.

21. Quan, J.; Liu, Q.; Li, X.; Gao, Y.; Jia, X.; Sheng, J.; Liu, Y., Effect of Heterogeneous Aqueous Reactions on the Secondary Formation of Inorganic Aerosols During Haze Events. Atmos. Environ. 2015, 122, 306-312.

22. He, H.; Wang, Y.; Ma, Q.; Ma, J.; Chu, B.; Ji, D.; Tang, G.; Liu, C.; Zhang, H.; Hao, J., Mineral Dust and Nox Promote the Conversion of So2 to Sulfate in Heavy Pollution Days. Sci. Rep. 2014, 4, 4172. 23. Kulmala, M.; Petäjä, T.; Kerminen, V.-M.; Kujansuu, J.; Ruuskanen, T.; Ding, A.; Nie, W.; Hu, M.; Wang, Z.; Wu, Z., On Secondary New Particle Formation in China. Frontiers of Environmental Science \& Engineering 2016, 10, 8 .

24. Che, H.; Xia, X.; Zhu, J.; Li, Z.; Dubovik, O.; Holben, B.; Goloub, P.; Chen, H.; Estelles, V.; Cuevas-Agulló, E., Column Aerosol Optical Properties and Aerosol Radiative Forcing During a Serious Haze-Fog Month over North China Plain in 2013 Based on Ground-Based Sunphotometer Measurements. Atmos. Chem. Phys. 2014, 14, 2125-2138.

25. Che, H. Z.; Xia, X. G.; Zhu, J.; Wang, H.; Wang, Y. Q.; Sun, J. Y.; Zhang, X. Y.; Shi, G. Y., Aerosol Optical Properties under the Condition of Heavy Haze over an Urban Site of Beijing, China. Environ. Sci. Pollut. Res. 2015, 22, 1043-1053.

26. Chen, W.; Tang, H. Z.; Zhao, H. M.; Yan, L., Analysis of Aerosol Properties in Beijing Based on Ground-Based Sun Photometer and Air Quality Monitoring Observations from 2005 to 2014. Remote Sensing 2016, 8, 110; doi:10.3390/rs8020110.

27. Chen, W.; Yan, L.; Ding, N.; Xie, M. D.; Lu, M.; Zhang, F.; Duan, Y. X.; Zong, S., Analysis of Aerosol Radiative Forcing over Beijing under Different Air Quality Conditions Using Ground-Based Sun-Photometers between 2013 and 2015. Remote Sensing 2016, 8, 510; doi:10.3390/rs8060510.

28. Hou, S. Q.; Tong, S. R.; Ge, M. F.; An, J. L., Comparison of Atmospheric Nitrous Acid During Severe Haze and Clean Periods in Beijing, China. Atmos. Environ. 2016, 124, 199-206.

29. Sun, L.; Li, R. B.; Tian, X. P.; Wei, J., Analysis of the Temporal and Spatial Variation of Aerosols in the Beijing-Tianjin-Hebei Region with a 1 Km Aod Product. Aerosol Air Qual. Res. 2017, 17, 923-935.

30. Zhang, Y.; Huang, W.; Cai, T. Q.; Fang, D. Q.; Wang, Y. Q.; Song, J.; Hu, M.; Zhang, Y. X., Concentrations and Chemical Compositions of Fine Particles (PM2.5) During Haze and Non-Haze Days in Beijing. Atmos. Res. 2016, 174, 62-69.

31. Lee, Y. N.; Schwartz, S. E., Kinetics of Oxidation of Aqueous Sulfur (IV) by Nitrogen Dioxide. In Precipitation Scavenging, Dry Deposition and Resuspension, Pruppacher, H. R.; Semonin, R. G.; Slinn, W. G. N., Eds. Elsevier: New York, 1983; Vol. 1, pp 453-466.

32. Cheng, Y.; Zheng, G.; Wei, C.; Mu, Q.; Zheng, B.; Wang, Z.; Gao, M.; Zhang, Q.; He, K.; Carmichael, G., Reactive Nitrogen Chemistry in Aerosol Water as a Source of Sulfate During Haze Events in China. Science Advances 2016, 2, e1601530; DOI: 10.1126/sciadv.1601530

33. Wang, G.; Zhang, R.; Gomez, M. E.; Yang, L.; Zamora, M. L.; Hu, M.; Lin, Y.; Peng, J.; Guo, S.; Meng, J., Persistent Sulfate Formation from London Fog to Chinese Haze. Proc. Natl. Acad. Sci. U. S. A. 2016, 113, 13630-13635.

34. Lammel, G.; Cape, J. N., Nitrous Acid and Nitrite in the Atmosphere. Chem. Soc. Rev. 1996, 25, 361-369.

35. Bambauer, A.; Brantner, B.; Paige, M.; Novakov, T., Laboratory Study of NO2 Reaction with Dispersed and Bulk Liquid Water. Atmos. Environ. 1994, 28, 3225-3232.

36. Cheung, J. L.; Li, Y. Q.; Boniface, J.; Shi, Q.; Davidovits, P.; Worsnop, D. R.; Jayne, J. T.; Kolb, C. E., Heterogeneous Interactions of NO2 with Aqueous Surfaces. J. Phys. Chem. A 2000, 104, 2655-2662.

37. Lee, Y. N.; Schwartz, S. E., Reaction-Kinetics of Nitrogen-Dioxide with Liquid Water at Low Partial-Pressure. J. Phys. Chem. 1981, 85, 840-848.

38. Mertes, S.; Wahner, A., Uptake of Nitrogen-Dioxide and Nitrous-Acid on Aqueous Surfaces. J. Phys. Chem. 1995, 99, 14000-14006. 
441

442

443

444

445

446

447

448

449

450

451

452

453

454

455

456

457

458

459

460

461

462

463

464

465

466

467

468

469

470

471

472

473

474

475

476

477

478

479

480

481

482

483

484

485

486

487

488

489

39. Novakov, T., Laboratory Study of $\mathrm{NO}_{2}$ Reaction with Dispersed and Bulk Liquid Water - Reply. Atmos. Environ. 1995, 29, 2559-2560.

40. Ponche, J. L.; George, C.; Mirabel, P., Mass-Transfer at the Air-Water-Interface - Mass Accommodation Coefficients of $\mathrm{SO}_{2}, \mathrm{HNO}_{3}, \mathrm{NO}_{2}$ and $\mathrm{NH}_{3}$. J. Atmos. Chem. 1993, 16, 1-21.

41. Schwartz, S. E.; Lee, Y. N., Laboratory Study of $\mathrm{NO}_{2}$ Reaction with Dispersed and Bulk Liquid Water. Atmos. Environ. 1995, 29, 2557-2559.

42. Colussi, A. J.; Enami, S.; Yabushita, A.; Hoffmann, M. R.; Liu, W. G.; Mishra, H.; Goddard, W. A., Tropospheric Aerosol as a Reactive Intermediate. Faraday Discussions 2013, 165, 407-420.

43. Enami, S.; Hoffmann, M. R.; Colussi, A., Absorption of Inhaled NO2. J. Phys. Chem. B 2009, 113, 7977-7981.

44. Kinugawa, T.; Enami, S.; Yabushita, A.; Kawasaki, M.; Hoffmann, M. R.; Colussi, A. J., Conversion of Gaseous Nitrogen Dioxide to Nitrate and Nitrite on Aqueous Surfactants. Phys. Chem. Chem. Phys. 2011, 13, 5144-5149.

45. Yabushita, A.; Enami, S.; Sakamoto, Y.; Kawasaki, M.; Hoffmann, M. R.; Colussi, A. J., AnionCatalyzed Dissolution of $\mathrm{NO}_{2}$ on Aqueous Microdroplets. J. Phys. Chem. A 2009, 113, 4844-4848.

46. Liu, M.; Song, Y.; Zhou, T.; Xu, Z.; Yan, C.; Zheng, M.; Wu, Z.; Hu, M.; Wu, Y.; Zhu, T., Fine Particle Ph During Severe Haze Episodes in Northern China. Geophys. Res. Lett. 2017, 44, 5213-5221.

47. Shi, G.; Xu, J.; Peng, X.; Xiao, Z.; Chen, K.; Tian, Y.; Guan, X.; Feng, Y.; Yu, H.; Nenes, A., pH of Aerosols in a Polluted Atmosphere: Source Contributions to Highly Acidic Aerosol. Environ. Sci. Technol. 2017, 51, 4289-4296.

48. Weber, R. J.; Guo, H.; Russell, A. G.; Nenes, A., High Aerosol Acidity Despite Declining Atmospheric Sulfate Concentrations over the Past 15 Years. Nat. Geosci. 2016, 9, 282-285.

49. Guo, H.; Nenes, A.; Weber, R. J., The Underappreciated Role of Nonvolatile Cations on Aerosol Ammonium-Sulfate Molar Ratios. Atmos. Chem. Phys. Discuss. 2017, doi.org/10.5194/acp-2017-737.

50. Guo, H.; Weber, R. J.; Nenes, A., High Levels of Ammonia Do Not Raise Fine Particle pH Sufficiently to Yield Nitrogen Oxide-Dominated Sulfate Production. Sci. Rep. 2017, 7, 12109.

51. He, K.; Zhao, Q.; Ma, Y.; Duan, F.; Yang, F.; Shi, Z.; Chen, G., Spatial and Seasonal Variability of Pm2. 5 Acidity at Two Chinese Megacities: Insights into the Formation of Secondary Inorganic Aerosols. Atmos. Chem. Phys. 2012, 12, 1377.

52. Xiyuan, C.; Pengzhen, H.; Zhuang Jiang, X. Y.; Fange, Y.; Longquan, W., Aerosol Acidity During Winter Heavy Haze Episodes in Beijing and Gucheng, China. J. Meteorol. Res. 2018, 32, doi: 10.1007/s13351-018-7063-4. (in press)

53. Lee, Y. N.; Schwartz, S. E., Reaction-Kinetics of Nitrogen-Dioxide with Liquid Water at Low Partial-Pressure. J. Phys. Chem. 1981, 85, 840-848.

54. Clifton, C. L.; Altstein, N.; Huie, R. E., Rate Constant for the Reaction of Nitrogen Dioxide with Sulfur (IV) over the pH Range 5.3-13. Environ. Sci. Technol. 1988, 22, 586-589.

55. Enami, S.; Colussi, A. J., Criegee Chemistry on Aqueous Organic Surfaces. J Phys. Chem. Lett. 2017, $8,1615-1623$.

56. Enami, S.; Hoffmann, M. R.; Colussi, A. J., Acidity Enhances the Formation of a Persistent Ozonide at Aqueous Ascorbate/Ozone Gas Interfaces. PNAS 2008, 105, 7365-7369.

57. Enami, S.; Hoffmann, M. R.; Colussi, A. J., Absorption of Inhaled $\mathrm{NO}_{2}$. J. Phys. Chem. B 2009, 113, 7977-7981.

58. Enami, S.; Hoffmann, M. R.; Colussi, A. J., Proton Availability at the Air/Water Interface. J. Phys. Chem. Lett. 2010, 1, 1599-1604.

59. Enami, S.; Hoffmann, M. R.; Colussi, A. J., OH-Radical Specific Addition to Glutathione S-Atom at the Air-Water Interface: Relevance to the Redox Balance of the Lung Epithelial Lining Fluid. J. Phys. Chem. Lett. 2015, 6, 3935-3943.

60. Enami, S.; Sakamoto, Y.; Colussi, A. J., Fenton Chemistry at Aqueous Interfaces. Proc. Natl. Acad. Sci. U. S. A. 2014, 111, 623-628. 
61. Enami, S.; Vecitis, C. D.; Cheng, J.; Hoffmann, M. R.; Colussi, A. J., Electrospray Mass Sxpostrometric Detection of Products and Short-Lived Intermediates in

62. Enami, S.; Hoffmann, M. R.; Colussi, A. J., Molecular Control of Reactive Gas Uptake "on Water". J. Phys. Chem. A 2010, 114, 5817-5822.

63. Enami, S.; Mishra, H.; Hoffmann, M. R.; Colussi, A. J., Hofmeister Effects in Micromolar Electrolyte Solutions. J. Chem. Phys. 2012, 136, 154707.

64. Enami, S.; Vecitis, C. D.; Cheng, J.; Hoffmann, M. R.; Colussi, A. J., Mass Spectrometry of Interfacial Layers During Fast Aqueous Aerosol/Ozone Gas Reactions of Atmospheric Interest. Chem. Phys. Lett. 2008, 455, 316-320.

65. Enami, S.; Stewart, L. A.; Hoffmann, M. R.; Colussi, A. J., Superacid Chemistry on Mildly Acidic Water. J. Phys. Chem. Lett. 2010, 1, 3488-3493.

66. Enami, S.; Colussi, A. J., Long-Range Specific Ion-Ion Interactions in Hydrogen-Bonded Liquid Films. J. Chem. Phys. 2013, 138, 184706.

67. Wennberg, P. O., Atmospheric Chemistry: Radicals Follow the Sun. Nature 2006, 442, 145-146.

68. Hung, H. M.; Hoffmann, M. R., Oxidation of Gas-Phase $\mathrm{SO} 2$ on the Surfaces of Acidic Microdroplets: Implications for Sulfate and Sulfate Radical Anion Formation in the Atmospheric Liquid Phase. Environ. Sci. Technol. 2015, 49, 13768-13776.

69. Fang, T.; Guo, H. Y.; Zeng, L. H.; Verma, V.; Nenes, A.; Weber, R. J., Highly Acidic Ambient Particles, Soluble Metals, and Oxidative Potential: A Link between Sulfate and Aerosol Toxicity. Environ. Sci. Technol. 2017, 51, 2611-2620.

70. Martin, L.; Hill, M.; Tai, A.; Good, T., The Iron Catalyzed Oxidation of Sulfur (IV) in Aqueous Solution: Differing Effects of Organics at High and Low pH J. Geophys. Res. Atmospheres 1991, 96, 3085-3097.

71. Liu, Y.; Wu, Z.; Wang, Y.; Xiao, Y.; Gu, F.; Zheng, J.; Tan, T.; Shang, D.; Wu, Y.; Zeng, L., Submicrometer Particles Are in the Liquid State During Heavy Haze Episodes in the Urban Atmosphere of Beijing, China. Environ. Sci. Technol. Lett. 2017, 4, 427-432.

72. Huang, R. J., et al., Concentration and Sources of Atmospheric Nitrous Acid (HONO) at an Urban Site in Western China. Sci. Total Environ. 2017, 593, 165-172.

73. Li, X., et al., Exploring the Atmospheric Chemistry of Nitrous Acid (HONO) at a Rural Site in Southern China. Atmos. Chem. Phys. 2012, 12, 1497-1513.

74. Li, Y.; An, J.; Kajino, M.; Li, J.; Qu, Y., Impacts of Additional HONO Sources on Concentrations and Deposition of Noy in the Beijing-Tianjin-Hebei Region of China. SOLA 2015, 11, 36-42.

75. Liu, Z.; Wang, Y. H.; Costabile, F.; Amoroso, A.; Zhao, C.; Huey, L. G.; Stickel, R.; Liao, J.; Zhu, T., Evidence of Aerosols as a Media for Rapid Daytime HONO Production over China. Environ. Sci. Technol. 2014, 48, 14386-14391.

76. Sörgel, M.; Regelin, E.; Bozem, H.; Diesch, J.-M.; Drewnick, F.; Fischer, H.; Harder, H.; Held, A.; Hosaynali-Beygi, Z.; Martinez, M., Quantification of the Unknown HONO Daytime Source and Its Relation to No 2. Atmos. Chem. Phys. Discuss. 2011, 11, 15119-15155.

77. Tang, Y.; An, J.; Wang, F.; Li, Y.; Qu, Y.; Chen, Y.; Lin, J., Impacts of an Unknown Daytime Hono Source on the Mixing Ratio and Budget of HONO, and Hydroxyl, Hydroperoxyl, and Organic Peroxy Radicals, in the Coastal Regions of China. Atmos. Chem. Phys. 2015, 15, 9381-9398.

78. Wang, L. W., et al., Hono and Its Potential Source Particulate Nitrite at an Urban Site in North China During the Cold Season. Sci. Total Environ. 2015, 538, 93-101.

79. Bian, Y.; Zhao, C.; Ma, N.; Chen, J.; Xu, W., A Study of Aerosol Liquid Water Content Based on Hygroscopicity Measurements at High Relative Humidity in the North China Plain. Atmos. Chem. Phys. 2014, 14, 6417-6426.

80. Tan, H.; Cai, M.; Fan, Q.; Liu, L.; Li, F.; Chan, P.; Deng, X.; Wu, D., An Analysis of Aerosol Liquid Water Content and Related Impact Factors in Pearl River Delta. Sci. Total Environ. 2017, 579, 1822-1830. 81. Martin, L. R.; Damschen, D. E.; Judeikis, H. S., The Reactions of Nitrogen Oxides with $\mathrm{SO}_{2}$ in Aqueous Aerosols. Atmos. Environ. (1967) 1981, 15, 191-195. 
541 82. Mendiara, S.; Ghibaudi, E.; Perissinotti, L.; Colussi, A., Free Radicals and Diradicals in the Reaction 542 between Nitrous Acid and Bisulfite in Acid Aqueous Media. J. Phys. Chem. 1992, 96, 8089-8091.

543 83. Littlejohn, D.; Wang, Y.; Chang, S. G., Oxidation of Aqueous Sulfite Ion by Nitrogen Dioxide. 544 Environ. Sci. Technol. 1993, 27, 2162-2167.

545 84. Oblath, S.; Markowitz, S.; Novakov, T.; Chang, S., Kinetics of the Initial Reaction of Nitrite Ion in 546 Bisulfite Solutions. J. Phys. Chem. 1982, 86, 4853-4857.

547 85. Li, Y.; An, J.; Gultepe, I., Effects of Additional HONO Sources on Visibility over the North China $548 \quad$ Plain. Advances in Atmospheric Sciences 2014, 31, 1221.

549 86. Riordan, E.; Minogue, N.; Healy, D.; O'Driscol, P.; Sodeau, J. R., Spectroscopic and Optimization 550 Modeling Study of Nitrous Acid in Aqueous Solution. J. Phys. Chem. A 2005, 109, 779-786.

551 87. Chu, L.; Anastasio, C., Temperature and Wavelength Dependence of Nitrite Photolysis in Frozen 552 and Aqueous Solutions. Environ. Sci. Technol. 2007, 41, 3626-3632. 


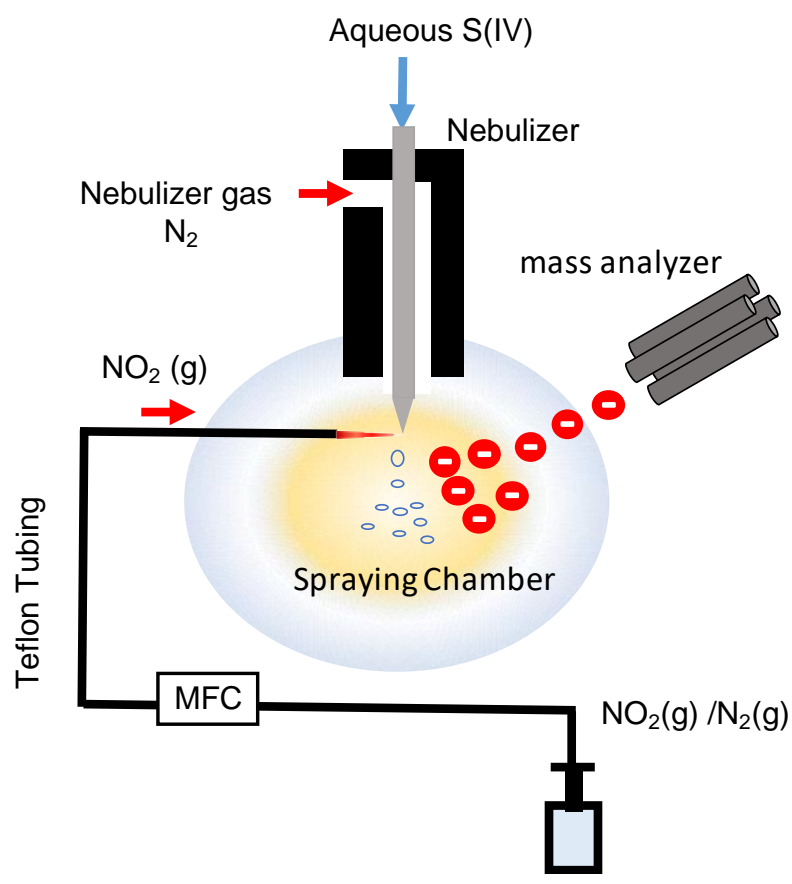

Figure 1. Schematic diagram of the experimental setup. MFC is the mass flow controller. 